\title{
Evaluation of structural-functional changes of the left ventricular myocardium in patients with arterial hypertension and obesity by the level of irisin
}

\author{
O. V. Shaparenko, P. H. Kravchun, P. P. Kravchun, O. I. Kadykova*, H. V. Lisova \\ Kharkiv National Medical University, Ukraine
} The aim was to evaluate the structural and functional changes of the left ventricular myocardium according to the data of
echocardiography in patients with arterial hypertension combined with obesity by the level of irisin.

Materials and methods. 105 patients were divided into 2 groups for participation in the study: the 1 group consisted of patients with arterial hypertension with concomitant obesity with concomitant obesity $(n=70)$, the group 2 - patients with arterial hypertension and normal body weight $(n=35)$. The control group consisted of 25 practically healthy persons. All participants of the study underwent irisin level measurement by an enzyme-linked immuno-sorbent assay and an echocardiographic examination with subsequent computer processing of the results using the software package Statistica 6.0 (StatSoft Inc., USA).

Results. In patients with arterial hypertension and obesity, hypoirisinemia (irisin level $<1.19 \pm 0.03 \mathrm{ng} / \mathrm{ml}$ ) was associated with an increase in the end-diastolic and systolic volumes by $31.57 \%(r=-0.44 ; P<0.05)$ and $20.70 \%(r=-0.53 ; P<0.05)$, sizes by $43.54 \%(r=-0.36 ; P<0.05)$ and $40.44 \%(r=-0.62 ; P<0.05)$ and decrease in the ejection fraction by $16.59 \%(r=0.41$; $P<0.05),(P<0.05)$.

Conclusions. Decrease in the content of serum irisin leads to structural and functional changes in the left ventricular myocardium in the form of myocardial contractility reduction and increase in both the cavity and size of the left ventricle, and can play a role in the pathogenesis of obesity in patients with arterial hypertension.
Key words: hypertension, obesity, irisin, haemodynamics.

Zaporozhye medical journal 2019; $21(1), 9-12$

DOI: $10.14739 / 2310-1210$ 2019.1.155783

*E-mail: kadykova.olga1985@ gmail.com

\section{Структурно-функціональні зміни міокарда лівого шлуночка у хворих на артеріальну гіпертензію та ожиріння за рівнем ірисину}

\section{О. В. Шапаренко, П. Г. Кравчун, П. П. Кравчун, О. І. Кадикова, Г. В. Аісова}

Мета роботи - оцінити структурно-функціональні зміни міокарда лівого шлуночка за даними ехокардіографії у хворих на артеріальну гіпертензію в поєднанні з ожирінням за рівнем ірисину.

Матеріали та методи. У дослідженні взяли участь 105 осіб, яких поділили на 2 групи: 1 - хворі на артеріальну гіпертензію 3 супутнім ожирінням ( $n=70), 2$ - хворі на артеріальну гіпертензію з нормальною масою тіла $(n=35)$. Контрольна група -25 практично здорових осіб. У всіх учасників дослідження визначили рівень ірисину імуноферментним методом і виконали ехокардіографічне дослідження з наступним комп'ютерним опрацюванням результатів за допомогою програмного пакета Statistica 6.0 (StatSoft Inc., США).

Результати. У хворих на артеріальну гіпертензію та ожиріння гіпоірисинемія (рівень ірисину $<1,19 \pm 0,03$ нг/мл) асоціювалася зі збільшенням кінцевих діастолічного та систолічного об'ємів на $31,57 \%$ ( $r=-0,44 ; p<0,05)$ і 20,70 \% ( $r=-0,53$; p < 0,05), розмірів - на 43,54 \% (r = -0,36; $p<0,05)$ і 40,44\% $(r=-0,62 ; p<0,05)$ та зменшенням фракції викиду на $16,59 \%$ $(r=0,41 ; p<0,05),(p<0,05)$.

Висновки. Зменшення вмісту в сироватці крові ірисину призводить до структурно-фрункціональних змін у міокарді лівого шлуночка, як-от зменшення його здатності до скорочення та збільшення порожнин і розмірів лівого шлуночка, може відіграти роль у патогенезі ожиріння у хворих на артеріальну гіпертензію.

\section{Структурно-функциональные изменения миокарда левого желудочка у больных артериальной гипертензией и ожирением по уровню ирисина}

\section{А. В. Шапаренко, П. Г. Кравчун, П. П. Кравчун, О. И. Кадыкова, А. В. Аесовая}

Цель работы - оценить структурно-функциональные изменения миокарда левого желудочка по данным эхокардиографии у больных артериальной гипертензией в сочетании с ожирением по уровню ирисина.

Материалы и методы. В исследовании приняли участие 105 пациентов, которых поделили на 2 группы: 1 - больные артериальной гипертензией с сопутствующим ожирением $(\mathrm{n}=70), 2$ - больные артериальной гипертензией с нормальной массой тела $(n=35)$. Контрольную группу составили 25 практически здоровых лиц. У всех участников исследования определили уровень ирисина иммуноферментным методом, провели эхокардиографическое исследование с последующей компьютерной обработкой результатов с помощью программного пакета Statistica 6.0 (StatSoft Inc., США).

Результаты. У больных артериальной гипертензией и ожирением гипоирисинемия (уровень ирисина <1,19 $\pm 0,03$ нг/мл) ассоциировалась с увеличением конечных диастолического и систолического объемов на $31,57 \%(r=-0,44 ; p<0,05)$ и $20,70 \%(r=-0,53, p<0,05)$, размеров - на 43,54 \% ( $r=-0,36 ; p<0,05)$ и 40,44\% $(r=-0,62 ; p<0,05)$ и уменьшением фрракции выброса на $16,59 \%(r=0,41 ; p<0,05),(p<0,05)$.
Ключові слова: артеріальна гіпертензія, ожиріння, ірисин, кардіогемодинаміка.

Запорізький медичний журнал. - 2019. T. 21, № 1(112). C. 9-12

Ключевые слова: артериальная гипертензия, ожирение, ирисин, кардиогемодинамика.

\section{Запорожский} медицинский журнал. - 2019. T. 21, № 1(112). C. $9-12$ 
Выводы. Уменьшение содержания в сыворотке крови ирисина приводит к структурно-функциональным изменениям в миокарде левого желудочка в виде уменьшения способности миокарда к сокращению и увеличения полостей и размеров левого желудочка и может играть роль в патогенезе ожирения у больных артериальной гипертензией.

The pathogenesis, course and prognosis of arterial hypertension $(\mathrm{AH})$ are closely related to the presence of such risk factors as the age of patients, sex, heredity, body weight, alimentary factors (kitchen salt, micro- and macro elements, coffee, alcohol), smoking, psychosocial factors, socio-economic status, physical activity and the presence of concomitant pathology, among which obesity occupies a significant place [1].

Comorbid pathology attracts the attention of researchers leading to our deepened understanding of its pathogenesis that would improve diagnosis and treatment for this cohort of patients and prevent the complications development. Many issues regarding the mechanisms of development and progression of cardiohemodynamics disorders in $\mathrm{AH}$ and obesity have not yet been properly determined. A promising important direction of modern science is the study of metabolic active substances capable of modulating total cardio-metabolic risk. Adipocytes produce a number of factors that play an important role regulating energy balance, tissue sensitivity to insulin action, immunological response, blood vessel and left ventricular (LV) myocardium state.

Recent researches have shown that irisin is also secreted by adipocytes [2,3]. Irisin is a newly discovered myokine secreted by skeletal muscle as a proteolytic cleavage product of the fibronectin type III domain-containing transmembrane protein 5 (FNDC5). Irisin stimulates UCP1 expression leading to the browning of white adipocytes. This transformation of adipocytes contributes to an increase in both glucose tolerance and insulin sensitivity, reduction of body weight and fat mass in mice [4,5].

The accumulated theoretical, experimental and clinical study data on factors affecting the development of cardio-metabolic disorders in patients with $\mathrm{AH}$ and obesity are ambiguous and require further study in order to refine the pathogenesis, optimize diagnosis, determine the prognosis and course of comorbid pathology as well as clarify and analyze pathogenetic mechanisms of factors interactions in glucose metabolic disorders and heart remodeling in patients with $\mathrm{AH}$ in combination with obesity. It will allow to detect prognostic markers for cardio-metabolic risk in patients with comorbid disorders.

\section{The objective}

The objective of the work is to evaluate the structural and functional changes of the left ventricular myocardium according to the data of echocardiography in patients with arterial hypertension combined with obesity by the level of irisin.

\section{Materials and methods}

The study included 105 patients, 56 of whom were women $(53.33 \%)$ and 49 were men $(46.67 \%)$. All patients were divided into 2 groups: the 1 group consisted of patients with arterial hypertension with concomitant obesity $(n=70)$, the group 2 - patients with arterial hypertension and normal body weight $(n=35)$. The average age of patients in the 1st group was $66.43 \pm 1.26$ years, and in the 2 nd group $-65.18 \pm 1.42$ years.

The control group consisted of 25 practically healthy persons, including 16 women (64\%) and 9 men (36\%). The average age of the control group was $59.7 \pm 3.27$ years.

According to the Helsinki Declaration, all patients were informed of a clinical trial and agreed to participate.

The participants of the study underwent irisin level measurement by using the Irisin ELISA KIT test kit (China) on the "Labline-90" immune enzyme analyzer (Austria)

Diagnosis was determined according to valid criteria. To characterize obesity, the body mass index (Kettle index) was calculated as follows: weight $(\mathrm{kg}) / \mathrm{height}\left(\mathrm{m}^{2}\right)$.

All patients underwent general clinical and instrumental examinations. Echocardiographic study was performed according to the standard method on an ultrasound apparatus RADMIR (Ultima PRO 30) (Kharkiv, Ukraine). The following LV parameters were determined by M-mode: end-diastolic size (EDS) (cm), end-systolic size (ESS) $(\mathrm{cm})$, posterior wall thickness (PWT) $(\mathrm{cm})$, interventricular septal thickness (IVST) (cm). The end-diastolic volume (EDV) and systolic volume (ESV) ( $\mathrm{ml}$ ) were estimated by the Simpson method (1991), after which the LV ejection fraction (EF) (\%) was calculated.

Mathematical computer processing of results was carried out with the help of the software package Statistica 6.0 (StatSoft Inc., USA). For comparative analysis of samples, a standard program of correlation analysis was used to calculate the arithmetic mean values: $\mathrm{M} \pm \mathrm{m}$, probability and reliability (p). In the analysis of variables that were not distributed normally, the Mann-Whitney U-criterion was used for independent samples. To estimate the relationship between the samples, the correlation coefficient ( $r$ ) was applied.

\section{Results}

In patients with $\mathrm{AH}$ and normal body mass, the level of irisin was $1.91 \pm 0.06 \mathrm{ng} / \mathrm{ml}$, which was significantly lower than that of the control group $(3.10 \pm 0.08 \mathrm{ng} / \mathrm{ml})(P<0.001)$. At the same time, in patients with hypertension and obesity, the level of irisin was $1.19 \pm 0.03 \mathrm{ng} / \mathrm{ml}$, which was significantly lower than that of the control group $(3.10 \pm 0.08 \mathrm{ng} / \mathrm{ml})$ and in the patients with normal body weight $(1.91 \pm 0.06 \mathrm{ng} / \mathrm{ml})$ $(P<0.001)$. Consequently, the content of irisin, according to the study results, is important in the development of obesity in patients with hypertension.

To determine the role of irisin in the structural and functional reorganization of the LV myocardium, the patients with $\mathrm{AH}$ and obesity were divided into subgroups depending on irisinemia: the 1 subgroup $-<1.19 \pm 0.03 \mathrm{ng} / \mathrm{ml}(n=31)$, the 2 subgroups $->1.19 \pm 0.03 \mathrm{ng} / \mathrm{ml}(\mathrm{n}=39)($ Table 1$)$.

EDV was $227.16 \pm 2.19 \mathrm{ml}$ and $155.44 \pm 2.34 \mathrm{ml}$ in the patients of subgroups 1 and 2 , respectively, in the patients of subgroup 2 EDV was less by $31.57 \%$ than in the patients of subgroup $1(P<0.05)$. ESV was $101.21 \pm 1.34 \mathrm{ml}$ and $80.26 \pm 1.42 \mathrm{ml}$ in the patients of subgroups 1 and 2, respectively, so ESV in the subgroup 2 patients was $20.70 \%$ lower than the subgroup 1 patients $(P<0.05)$. EDS 
was $7.28 \pm 0.06 \mathrm{~cm}$ and $4.11 \pm 0.07 \mathrm{~cm}$ in the patients of subgroups 1 and 2, respectively. EDS was $43.54 \%$ lower in the subgroup 2 patients compared with the subgroup 1 $(P<0.05)$. In the patients of subgroups 1 and 2, the ESS indices were $5.86 \pm 0.05 \mathrm{~cm}$ and $3.49 \pm 0.04 \mathrm{~cm}$, respectively, and this index was $40.44 \%$ lower in the subgroup 2 patients compared with the subgroup $1(P<0.05)$. The left atrial sizes were $4.77 \pm 0.05 \mathrm{~cm}$ and $3.26 \pm 0.07 \mathrm{~cm}$ in the patients of subgroups 1 and 2, respectively; in the subgroup 2 patients the left atrial size was $31.66 \%$ smaller than in the patients of subgroup $1(P<0.05)$. The same trend was observed for of left ventricular myocardium mass (MMLV): $284.56 \pm 6.6 \mathrm{~g}$ and $217.31 \pm 5.9 \mathrm{~g}$ in the patients of subgroups 1 and 2, respectively, so this index was lower by $23.63 \%$ in the subgroup 2 patients compared with that in the patients of subgroup $1(P<0.05)$. On the contrary, EF was lower by $16.59 \%$ in subgroup 1 patients than in the patients of subgroup 2, and amounted to $49.32 \pm 0.61 \%$ and $59.13 \pm 0.73 \%$ in the patients of subgroups 1 and 2 $(P<0.05)$, respectively.

The above results were presented in the correlation analysis that revealed a strong negative correlation between irisin level and the EDV $(r=-0.44 ; P<0.05)$, ESV $(r=-0.53$; $P<0.05)$, FDS $(r=-0.36 ; P<0.05)$, FSS $(r=-0.62$; $P<0.05)$, MMLV $(r=-0.29 ; P<0.05)$, whereas positive correlation was found between irisin level and $E F(r=0.41$; $P<0.05)$ and IVST $(r=0.36 ; P<0.05)$.

\section{Discussion}

According to the results of our studies, the combined course of $\mathrm{AH}$ and obesity was associated with a decrease in the serum content of irisin. The association of the irisin level with obesity was investigated by M. Belviranli and co-authors who also obtained negative correlation between irisin and insulin levels $(r=-0.648$; $P<0.05)$, HOMA-IR $(r=-0.664$; $P<0.05)[6]$. While T. Kurdiova and co-authors found lower levels of serum irisin in obese men than non-obese men and increased expression of FNDC5 (irisin precursor protein) mRNA in skeletal muscle and adipose tissue in obese men, indicating that irisin secretion in these tissues is stimulated in response to obesity [7]. Roca-Rivada A. and co-authors found expression of FNDC5 mRNA in white adipose tissue and involvement of adiponectin in irisin levels regulation in obesity [2]. Liu J.J. and co-authors showed that irisin levels were high in patients with non-diabetic obesity and lower in patients with type 2 diabetes mellitus, indicating that the regulation of irisin secretion may vary between diabetics and nondiabetics. In addition, there were reports about a mechanism that stimulates the compensatory irisin secretion in response to a decrease in glucose / lipid metabolism in patients with non-diabetic obesity [8]. These studies show the complexity of the secretory response of irisin, and, in particular, feedback mechanisms in tissues other than skeletal muscle. It has previously been established that irisin secreted in the blood increases insulin resistance by increasing the expression of the uncoupling protein 1 gene (UCP1) [9].

The role of irisin in human physiology remains largely unknown despite recently published studies. High irisin concentration causes a loss of ATP because of its uncoupling properties and decreased irisin level protects
Table 1. Structural and functional changes of the left ventricular myocardium in patients with arterial hypertension and obesity depending on irisinemia $(\mathrm{M} \pm \mathrm{m})$

\begin{tabular}{|c|c|c|c|}
\hline $\begin{array}{l}\text { Subgroups } \\
\text { Indexes }\end{array}$ & $\begin{array}{l}\text { Subgroup 1, } \\
(n=31)\end{array}$ & $\begin{array}{l}\text { Subgroup 2, } \\
(\mathrm{n}=39)\end{array}$ & $P$ \\
\hline EDV, ml & $227.16 \pm 2.19$ & $155.44 \pm 2.34$ & $<0.05$ \\
\hline ESV, ml & $101.21 \pm 1.34$ & $80.26 \pm 1.42$ & $<0.05$ \\
\hline EDS, $\mathrm{cm}$ & $7.28 \pm 0.06$ & $4.11 \pm 0.07$ & $<0.05$ \\
\hline ESS, cm & $5.86 \pm 0.05$ & $3.49 \pm 0.04$ & $<0.05$ \\
\hline$E F, \%$ & $49.32 \pm 0.61$ & $59.13 \pm 0.73$ & $<0.05$ \\
\hline IVST, $\mathrm{cm}$ & $1.43 \pm 0.04$ & $1.42 \pm 0.04$ & $>0,05$ \\
\hline Left atrium, cm & $4.77 \pm 0.05$ & $3.26 \pm 0.07$ & $<0.05$ \\
\hline Aorta, $\mathrm{cm}$ & $3.08 \pm 0.02$ & $3,06 \pm 0,03$ & $>0.05$ \\
\hline MMLV, g & $284.56 \pm 6.60$ & $217.31 \pm 5.90$ & $<0.05$ \\
\hline
\end{tabular}

myocardial cells from energy loss. Cardiac muscle cells produce more irisin than skeletal muscle [4]. Recently, a link between myocardial infarction and circulating irisin concentration was suggested [10]. Aronis et al. [11] demonstrated that circulating irisin levels do not predict the development of acute coronary syndrome in healthy individuals, however increased irisin levels prospectively predict the development of major advanced cardiovascular outcomes in patients with established coronary artery disease after percutaneous coronary intervention. Their study was the first in evaluating the relationship between circulating irisin levels and acute coronary syndrome in human subjects, as well as clinical outcomes in patients with established coronary artery disease. In a study with animal models, Kuloglu et al. [12] showed that serum irisin level was gradually decreased in the isoproterenol-induced myocardial infarction.

Our study had some limitations. Firstly, this study had a relatively small sample size of selected patients. Secondly, it was a cross-sectional study. Irisin concentration was measured only on admission and without correction for potential variability in the levels. Further large, multicenter follow up studies are needed to confirm this relation.

\section{Conclusions}

Decrease in the content of serum irisin leads to structural and functional changes in the left ventricular myocardium in the form of myocardial contractility reduction and increase in both the cavity and size of the left ventricle, and can play a role in the pathogenesis of obesity in patients with arterial hypertension.

Prospects for further research. The study of the peculiarities of structural and functional changes in the LV myocardium in patients with hypertension and obesity as well as the study of humoral factors influence on LV remodeling will allow optimizing the treatment tactics for this cohort of patients and developing measures for the prevention of complications.

Conflicts of interest: authors have no conflict of interest to declare. Конфмікт інтересів: віАсутній.

Information about authors:

Shaparenko 0. V., MD, Postgraduate student of the Department of Internal Medicine \# 2 and Clinical Immunology and Allergology, Kharkiv National Medical University, Ukraine. 
Kravchun P. H., MD, PhD, DSc, Professor, Head of the Department of Internal Medicine \# 2 and Clinical Immunology and Allergology, Kharkiv National Medical University, Ukraine.

Kravchun P. P., MD, PhD, Dsc, Associate Professor of the Department of Internal Medicine \# 2 and Clinical Immunology and Allergology, Kharkiv National Medical University, Ukraine. Kadykova O. I., MD, PhD, Assistant of the Department of Internal Medicine \# 2 and Clinical Immunology and Allergology, Kharkiv National Medical University, Ukraine.

Lisova H. V., PhD, Associate Professor of the Department of Public Health and Healthcare Management, Kharkiv National Medical University, Ukraine.

ORCID ID: 0000-0003-1102-1838

\section{Відомості про авторів:}

Шапаренко О. В., аспірант каф. внутрішньої медицини № 2 і клінічної імунології та алергології, Харківський національний медичний університет, Україна.

Кравчун П. Г., А-р меА. наук, професор, зав. каф. внутрішньої меАицини № 2 і кмінічної імунології та алергології, Харківський національний меАичний університет, Україна.

Кравчун П. П., А-р меА. наук, Аоцент каф. внутрішньої медицини № 2 і кмінічної імунології та алергології, Харківський національний медичний університет, Україна.

Кадикова О. І., канА. меА. наук, асистент каф. внутрішньої медицини № 2 і кмінічної імунології та алергології, Харківський національний медичний університет, Україна.

Аісова Г. В., канА. меА. наук, Аоцент каф. громадського зАоров'я та управління охороною зАоров'я, Харківський національний медичний університет, Україна.

\section{Сведения об авторах:}

Шапаренко А. В., аспирант каф. внутренней медицины № 2 и клинической иммунологии и аммергологии, Харьковский национальный медицинский университет, Украина. Кравчун П. Г., А-р меА. наук, профессор, зав. каф. внутренней медицины № 2 и клинической иммунологии и амеегологии, Харьковский национальный медицинский университет, Украина. Кравчун П. П., А-р меА. наук, Аоцент каф. внутренней медицины № 2 и клинической иммунологии и аммергологии, Харьковский национальный медицинский университет, Украина.

Кадыкова О. И., канА. меА. наук, ассистент каф. внутренней медицины № 2 и клинической иммунологии и амеергологии, Харьковский национальный меАицинский университет, Украина.

Лесовая А. В., канА. меА. наук, доцент каф. общественного зАоровья и управления зАравоохранением, Харьковский национальный медицинский университет, Украина.

Надійшла Ао реАакції / Received: 13.04.2018

Після Аоопрацювання / Revised: 16.05.2018

Прийнято АО Аруку / Accepted: 29.05.2018

\section{References}

[1] Kovalenko, V. M., Kornatskyi, V. M., et al. (2014). Khvoroby systemy krovoobihu yak medyko-sotsialna i suspilno-politychna problema [Diseases of the circulatory system as a medical and social and socio-political problem]. Kyiv. [in Ukrainian].

[2] Roca-Rivada, A., Castelao, C., Senin, L. L., Landrove, M. O., Baltar, J., Belén Crujeiras, A., et al. (2013). FNDC5/irisin is not only a myokine but also an adipokine. PLoS One, 8(4), e60563. doi: 10.1371/journal. pone. 0060563

[3] Moreno-Navarrete, J. M., Ortega, F., Serrano, M., Guerra, E., Pardo, G., Tinahones F., et al. (2013). Irisin is expressed and produced by human muscle and adipose tissue in association with obesity and insulin resistance. J. Clin. Endocrinol. Metab., 98(4), E769-E778. doi: 10.1210/jc.2012-2749.

[4] Boström, P., Wu, J., Jedrychowski, M. P., Korde, A., Ye, L., Lo, J. C., et al. (2012). APGC1-alpha-dependent myokine that drives brown-fat-like development of white fat and thermogenesis. Nature, 481 (7382), 463-8. doi: 10.1038/nature10777.

[5] Stanford, K. I., Middelbeek, R. J., Townsend, K. L., An, D., Nygaard, E. B., Hitchcox, K. M, et al. (2013). Brown adipose tissue regulates glucose homeostasis and insulin sensitivity. J. Clin. Invest., 123(1), 215-23. doi: 10.1172/JCI62308.
[6] Belviranli, M., Okudan, N., \& Çelik F. (2016). Association of Circulating Irisin with Insulin Resistance and Oxidative Stress in Obese Women. Horm. Metab. Res., 48(10), 653-657. doi: 10.1055/s-0042116155.

[7] Kurdiova, T., Balaz, M., Vician, M., Maderova, D., Vlcek, M., Valkovic, L., et al. (2014). Effects of obesity, diabetes and exercise on FNDC5 gene expression and irisin release in human skeletal muscle and adipose tissue: in vivo and in vitro studies. J. Physiol., 592(5), 1091-107. doi: 10.1113/jphysiol.2013.264655.

[8] Liu, J. J., Wong, M. D., Toy, W. C., Tan, C. S., Liu, S., Ng, X. W., et al. (2013). Lower circulating irisin is associated with type 2 diabetes mellitus. J. Diabetes Complications, 27(4), 365-9. doi: 10.1016/j. jdiacomp.2013.03.002

[9] Sanchis-Gomar, F., \& Perez-Quilis, C. (2014). The p38-PGC-1a-irisin-betatrophin axis: exploring new pathways in insulin resistance. Adipocyte, 3(1), 67-8. doi: 10.4161/adip.27370.

[10] Park, S. E., Park, C. Y., \& Sweeney, G. (2015). Biomarkers of insulin sensitivity and insulin resistance: Past, present and future. Crit. Rev. Clin. Lab. Sci., 52(4), 180-90. doi: 10.3109/10408363.2015.1023429.

[11] Aronis, K. N., Moreno, M., Polyzos, S. A., Moreno-Navarrete, J. M., Ricart, W., Delgado, E., et al. (2015). Circulating irisin levels and coronary heart disease: association with future acute coronary syndrome and major adverse cardiovascular events. Int J Obes (Lond), 39(1), 156-61. doi: 10.1038/ijo.2014.101.

[12] Kuloglu, T., Aydin, S., Eren, M. N., , Yilmaz, M., Sahin, I., Kalayci, M., et al. (2014). Irisin: a potentially candidate marker for myocardial infarction Peptides, 55, 85-91. doi: 10.1016/j.peptides.2014.02.008. 